\title{
Tissue spaces during development and regression of the decidual cell reaction in ovariectomized, steroid-treated mice
}

\author{
S. R. Milligan and C. Edwards \\ Department of Physiology, King's College, Strand, London WC2R 2LS, UK
}

\begin{abstract}
Summary. Changes in the extracellular and blood spaces of the uterus were assessed from the distribution volumes of ${ }^{51} \mathrm{Cr}$-EDTA and ${ }^{51} \mathrm{Cr}$-labelled red blood cells during the development and regression of the artificially induced decidual cell reaction in ovariectomized, steroid-treated mice. The normally high values for uterine extracellular space $(0.35-0.40 \mu \mathrm{l} / \mathrm{mg})$ fell to less than $0.20 \mu \mathrm{l} / \mathrm{mg}$ in association with decidual growth. Uterine blood space increased from around $0.02 \mu \mathrm{l} / \mathrm{mg}$ to $0.03-0.05 \mu \mathrm{l} / \mathrm{mg}$ with decidual development. Induction of decidual regression by removal of s.c. progesterone implants caused a rapid decline in tissue blood volume to reach control values $(0.01-0.02 \mu \mathrm{l} / \mathrm{mg})$ within $24 \mathrm{~h}$ and preceded any reduction in uterine weight. Uterine vascular permeability, as determined from the tissue accumulation of ${ }^{125} \mathrm{I}$ labelled human serum albumin, fell with a similar time course. Tissue extracellular space returned to the higher control values within $48 \mathrm{~h}$ of initiating decidual regression.
\end{abstract}

Keywords: mouse; decidual cell reaction; tissue space

\section{Introduction}

Knowledge of the volume of extracellular space in a tissue is fundamental to studies of the exchange of metabolites, paracrine and endocrine signals between the extracellular and cellular compartments. Changes in extracellular space occur physiologically and reflect complex balances between blood flow, vascular permeability, lymphatic drainage and cellular development.

A characteristic feature of the uterus is a large extracellular tissue compartment (Spaziani, 1975), the volume of which changes markedly during normal physiological conditions. Most quantitative studies on uterine tissue spaces have been undertaken with non-pregnant uteri: for the rat, estimates of the extracellular space have been in the region of $0.4-0.5 \mu \mathrm{l} / \mathrm{mg}$ (i.e. $40-50 \%$ ) depending on the extracellular marker employed (Spaziani \& Gutman, 1965). A localized increase in extracellular space occurs in the stroma surrounding the implanting blastocyst and is a result of a localized increase in vascular permeability (Psychoyos, 1960; Finn \& McLaren, 1967; McRae \& Heap, 1988). This is followed by a major morphological change within the uterine stroma-the development of the decidual cell reaction (Finn, 1977). The cellular changes involved in decidualization include enlargement, the development of polyploidy and the acquisition of junctional complexes between cells (Finn, 1977). Large sinusoids form in intimate contact with the decidual cells. Later regression of the decidual tissue is associated with a rapid reduction in blood flow (Edwards \& Milligan, 1987), invasion by leucocytes and cellular degeneration (Finn \& Pope, 1984, 1986).

In view of these major morphological changes accompanying the development and later regression of the decidual tissue, changes in the normally large extracellular space of the uterus would not be unexpected. No studies of this have previously been made, despite its potential importance in influencing the structural and physiological characteristics of the tissue. The present 
study was undertaken to investigate the quantitative changes in extracellular and vascular spaces accompanying decidual growth and regression.

\section{Materials and Methods}

Animals. Adult Swiss albino female mice (A. Tuck \& Son Ltd, Battlesbridge, Essex, UK), 2- 4 months of age, weighing $25-40 \mathrm{~g}$, were fed on a pelleted diet (41 B Oxoid) and housed at $21^{\circ} \mathrm{C}$ with lights on from 08:00 to 24:00 h. Ovariectomies were performed under ether anaesthesia at least 2 weeks before use. Steroids (Sigma London Chemical Co. Ltd, Poole, Dorset, UK) were administered by subcutaneous (s.c.) injection (progesterone and oestradiol- $17 \beta$ : $0 \cdot 1 \mathrm{ml}$ in arachis oil vehicle) or by s.c. Silastic (Dow Corning, Midland, MI, USA) implants (progesterone alone). The implants were $1 \mathrm{~cm}$ in length, i.d. $1.58 \mathrm{~mm}$, o.d. $3.18 \mathrm{~mm}$, and contained a suspension of progesterone in oil; such implants produce plasma concentrations of progesterone similar to those in the first half of pregnancy (S. R. Milligan, unpublished).

Ovariectomized mice were primed with $100 \mathrm{ng}$ oestradiol for 3 days, followed by 2 days of no treatment, followed by 3 daily injections of $10 \mathrm{ng}$ oestradiol in combination with either daily injections of 1 mg progesterone (Exp. 1) or placement of a progesterone containing implant (Exp. 2): this produces maximal sensitivity to a decidual stimulus on the 3rd day of combined progesterone and oestradiol treatment (Finn \& Martin, 1972). Intrauterine instillation of $10 \mu l$ arachis oil was then performed on one uterine horn to induce decidualization. Further progesterone support was provided by continued daily injection or by leaving the progesterone implant in place.

Estimations of tissue spaces. Quantitative estimates of tissue blood volume were obtained from the tissue content of ${ }^{51} \mathrm{Cr}$-labelled red cells, as described previously for rats (Milligan \& Mirembe, 1984). Under tribromoethanol (Exp. 1) or ether (Exp. 2) anaesthesia, approximately $100 \mu \mathrm{l}(25 \mu \mathrm{Ci})$ of ${ }^{51} \mathrm{Cr}$-labelled mouse red cells were injected into the external jugular. In some experiments, this was combined with the injection of ${ }^{125}$ I-labelled human serum albumin (HSA) for assessment of uterine vascular permeability (Milligan, 1987). After $30 \mathrm{~min}$, a blood sample was obtained from the sub-orbital canthal sinus and the animal killed by cervical dislocation. Tissue samples were rinsed in $0.9 \%$ $(w / v) \mathrm{NaCl}$, weighed and their content of radioactive markers determined using a Nuclear Enterprises automatic gamma counter (with appropriate correction for cross-over of the energy spectra of ${ }^{51} \mathrm{Cr}$ and ${ }^{125} \mathrm{I}$ ). Tissue blood volumes were determined from the relative content of ${ }^{51} \mathrm{Cr}$ in the blood and tissue samples on the assumption that tissue and systemic haematocrits were identical. Extravascular ${ }^{125}$ I-labelled HSA accumulation was determined on the assumption that all ${ }^{125} \mathrm{I}$ was protein bound.

Extracellular space was estimated from the volume of distribution of ${ }^{51} \mathrm{Cr}$-ethylenediaminetetraacetate $\left({ }^{51} \mathrm{Cr}\right.$ EDTA) (Foreman et al., 1953). This substance rapidly distributes within extracellular space after injection but is unabie to cross cell membranes and is not concentrated by any organ (Foreman et al., 1953). Mice were anaesthetized using tribromoethanol anaesthesia and their renal pedicles ligated to prevent depletion of circulating label through renal loss. ${ }^{51} \mathrm{Cr}$-EDTA $(5 \mu \mathrm{Ci}$ in $50 \mu \mathrm{l})$ was injected via the external jugular vein. In an initial study, mice were killed 30,45 and 60 min later to assess the effect of various circulation times. In later experiments, all mice were killed after a circulation time of the ${ }^{51} \mathrm{Cr}$-EDTA of $30 \mathrm{~min}$. In all experiments, a blood sample $(\sim 125 \mu \mathrm{l})$ was taken from the suborbital canthal sinus immediately before death. Tissue extracellular space ( ${ }^{51} \mathrm{Cr}$-EDTA distribution volume) was determined using the expression:

$$
\text { extracellular space }=\frac{\mathrm{Cr} \text { c.p.m. } / \mathrm{mg} \text { tissue }}{\mathrm{Cr} \text { c.p.m. } / \mu \mathrm{l} \text { plasma }}
$$

Assessments of blood space, extracellular space and vascular permeability were performed on the experimental (decidualized) uterine horn, the contralateral (control) horn, and (in Exp. 1) samples of upper thigh muscles (tensor fasciae latae and vastus lateralis) and liver.

Experiment 1. Changes in tissue blood volume and extracellular space were determined at 24-h intervals after the initial intrauterine stimulus for decidualization. Progesterone support was provided by daily injection.

Experiment 2. Changes in tissue blood volume, extracellular space and vascular permeability were determined during regression of the decidual cell reaction. Progesterone support for decidualization was initially provided by progesterone-containing implants. The implants were removed using brief ether anaesthesia $96 \mathrm{~h}$ after decidual induction and the tissue changes assessed after $6,12,24,36$ and $48 \mathrm{~h}$. A sham operation for removal of the implants was performed in some animals and assessments of tissue spaces made at 24 and $48 \mathrm{~h}$.

Analysis of results. Results were analysed using Student's paired and unpaired $t$ tests, or analysis of variance followed by Duncan's New Multiple Range Test (Li, 1957), as appropriate.

\section{Results}

In initial experiments using ${ }^{51} \mathrm{Cr}$-EDTA as the extracellular marker, no significant differences were observed in the estimates of extracellular space in any tissue after circulation times of 30,45 , or $60 \mathrm{~min}$ (Table 1). In all later experiments, a circulation time of $30 \mathrm{~min}$ was used. 
Table 1. ${ }^{51} \mathrm{Cr}$-EDTA space* in mouse tissues after various circulation times of ${ }^{51} \mathrm{Cr}$-EDTA

\begin{tabular}{|c|c|c|c|c|}
\hline \multirow{3}{*}{$\begin{array}{l}{ }^{51} \mathrm{Cr} \text {-EDTA } \\
\text { circulation } \\
\text { time (mins) }\end{array}$} & \multicolumn{4}{|c|}{${ }^{51} \mathrm{Cr}$-EDTA space $(\mu \mathrm{l} / 100 \mathrm{mg})$} \\
\hline & \multicolumn{2}{|c|}{ Uterus } & \multirow[b]{2}{*}{ Muscle } & \multirow[b]{2}{*}{ Liver } \\
\hline & $\begin{array}{l}\text { Decidualized } \\
\text { horn }\end{array}$ & $\begin{array}{c}\text { Control } \\
\text { horn }\end{array}$ & & \\
\hline 30 & $42 \cdot 0 \pm 1 \cdot 1$ & $35 \cdot 7 \pm 1 \cdot 7$ & $10.6 \pm 0.8$ & $17 \cdot 0 \pm 1 \cdot 2$ \\
\hline 45 & $43 \cdot 6 \pm 2 \cdot 0$ & $39 \cdot 1 \pm 2.9$ & $14.8 \pm 2.4$ & $16.9 \pm 0.9$ \\
\hline 60 & $43.7 \pm 0.8$ & $36 \cdot 4 \pm 2 \cdot 1$ & $11.7 \pm 0.9$ & $15.9 \pm 0.5$ \\
\hline
\end{tabular}

Values are mean \pm s.e.m. for 7 observations.

${ }^{*} 100 \times{ }^{51} \mathrm{Cr}$ c.p.m./mg tissue

${ }^{51} \mathrm{Cr}$ c.p.m./ $/$ l plasma

\section{Experiment 1}

After the induction of decidualization, the weight of the decidualized uterine horn rose over the course of the next 4-5 days (Fig. 1a). This was accompanied by a small, gradual increase in relative blood volume (Fig. Ib): this was significantly higher than in the contralateral, control horns at 48 , 72,96 and $120 \mathrm{~h} .{ }^{51} \mathrm{Cr}$-EDTA space in the decidualized horn showed an initial increase over control levels at $24 \mathrm{~h}$, but was significantly lower than in the control uterine horn $72-120 \mathrm{~h}$ after decidual induction. The extracellular space fell further between 120 and $144 \mathrm{~h}$, to reach a mean value of less than $0.15 \mu \mathrm{l} / \mathrm{mg}$ by $144 \mathrm{~h}$ (Fig. Ic). The declines in uterine weight, blood volume and extracellular space at $144 \mathrm{~h}$ may reflect the natural regression of the decidual tissue which eventually occurs even in the continuing presence of progesterone (Finn, 1977).

There were no significant changes in either blood volume or extracellular space in the control (non-decidualized) uterine horn or in either of the other control tissues (liver, muscle) over the period of investigation (Fig. 1).

\section{Experiment 2}

Immediately before the removal of the progesterone implant ( $96 \mathrm{~h}$ after decidual induction), uterine blood volume and vascular permeability in the decidualized horn were considerably higher, and extracellular space lower, than in the control horn (Fig. 2). Removal of the progesterone implant induced decidual regression, with a marked reduction in uterine weight within $48 \mathrm{~h}$ (Fig. 2a). This was preceded by a rapid fall in uterine blood volume between 6 and $24 \mathrm{~h}$ after implant removal, reaching control values by $24 \mathrm{~h}$ (Fig. 2b). The high vascular permeability (as reflected in the accumulation of ${ }^{125} \mathrm{I}$-labelled HSA) of the decidualized uterus fell sharply over the 12 -h period after removal of the progesterone-containing implant (Fig. 2d). A reduction in extracellular space in the decidualized uterine horn occurred $24-36 \mathrm{~h}$ after implant removal, returning to control values by $48 \mathrm{~h}$ (Fig. $2 \mathrm{c}$ ).

\section{Discussion}

This study of tissue spaces extends previous observations of uterine extracellular space (e.g. Spaziani \& Gutman, 1965; Spaziani, 1975) by showing that although the uterine extracellular compartment is very large in comparison with most other tissues (e.g. rat skeleta! muscle: 8-13\%; rat liver: $10-20 \%$, Law, 1982; also see Table 1), significant changes accompany both decidual growth and decidual regression. 

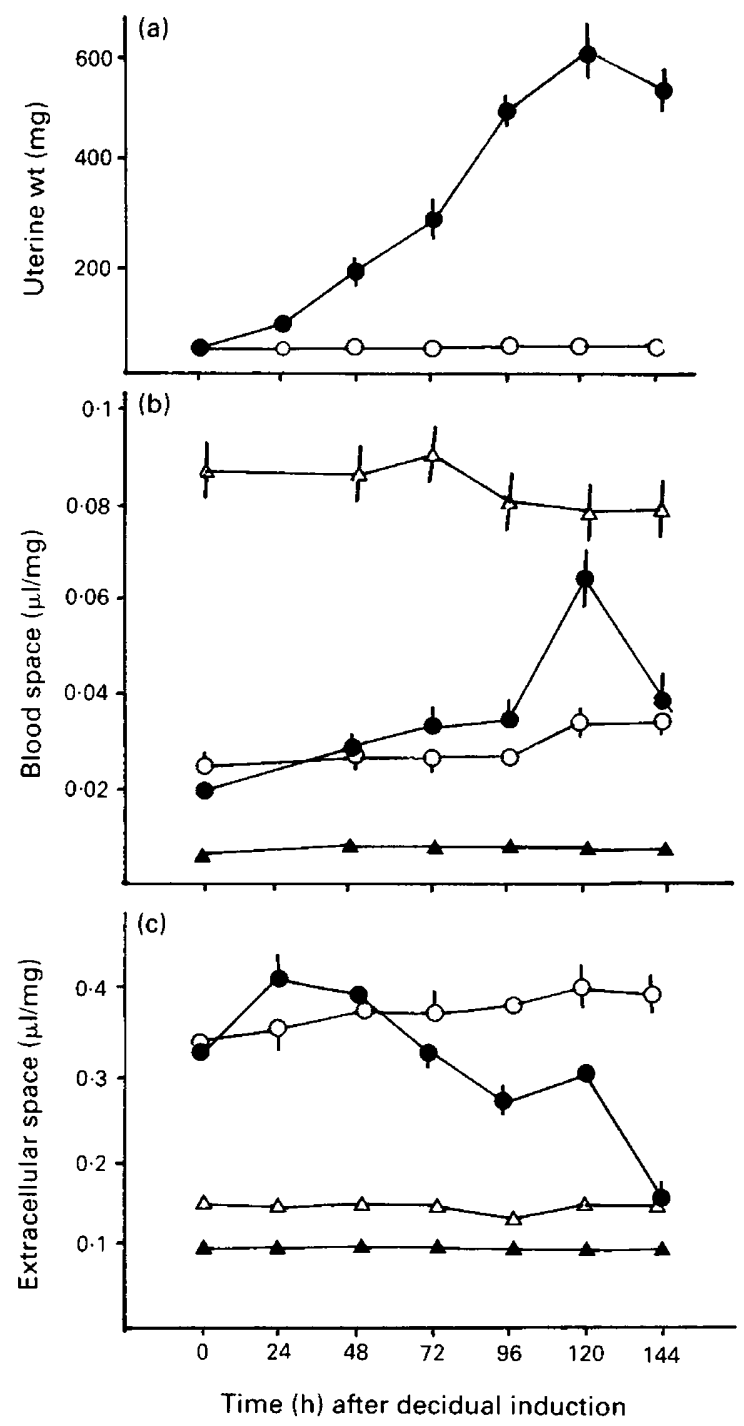

Fig. 1. Changes in (a) uterine weight, (b) tissue blood space (assessed by the distribution of ${ }^{51} \mathrm{Cr}$-labelled red cells), and (c) tissue extracellular space (assessed by the distribution of ${ }^{51} \mathrm{Cr}$ EDTA) during the development of the decidual cell reaction in mice $(O$, control uterine horn; - decidualized horn; $\boldsymbol{\Delta}$, muscle; $\Delta$, liver). Decidualization was induced at time 0 by the induction of $10 \mu \mathrm{l}$ arachis oil into one uterine horn. Values are means \pm s.e.m. $(n=7-9$ per point).

The early increase in extracellular $\left({ }^{51} \mathrm{Cr}\right.$-EDTA) space $24 \mathrm{~h}$ after the decidual stimulus is consistent with histological studies (Finn \& Pope, 1986) and may be a consquence of the increased vascular permeability that precedes decidualization. In rats and mice, a marked increase in uterine vascular permeability to ${ }^{125} \mathrm{I}$-labelled albumin occurs in association with implantation (Milligan \& Mirembe, 1984; McRae \& Heap, 1988) and occurs within a few hours of the application of an artificial decidual stimulus (Milligan \& Mirembe, 1984, 1985). In addition, blood flow to early implantation sites increases very significantly (McRae \& Heap, 1988). Such responses emphasize the close similarity between some aspects of implantation and inflammatory responses (Finn, 1986). 

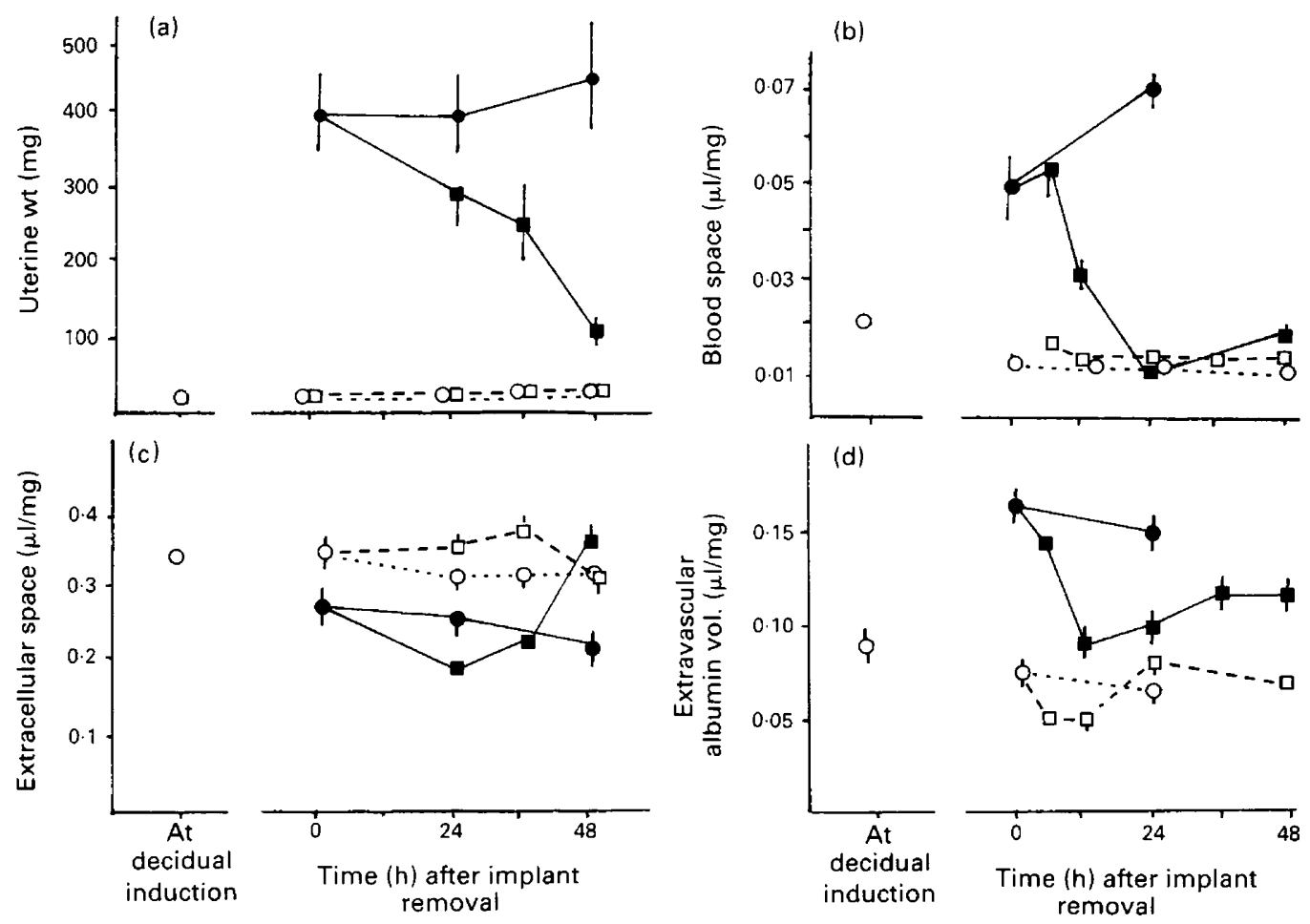

Fig. 2. Changes in (a) uterine weight, (b) tissue blood space (assessed by the distribution of ${ }^{51} \mathrm{Cr}$-labelled red cells), (c) tissue extracellular space (assessed by the distribution of ${ }^{51} \mathrm{Cr}$ EDTA) and (d) vascular permeability (assessed by the distribution of ${ }^{125}$ I-labelled human serum albumin) in the decidual cell reaction in mice following the withdrawal of progesterone support. Decidualization was induced by the induction of $10 \mu \mathrm{l}$ arachis oil into one uterine horn and decidualization was supported by the presence of a subcutaneous progesterone implant. Tissue spaces were determined in the control (non-decidualized: open symbols) and decidualized (closed symbols) uterine horns following removal $(\square, \boldsymbol{\square})$ or sham removal $(\bigcirc, 0)$ of the progesterone implant 4 days later (time 0$)$. Values are means \pm s.e.m. $(n=7-9$ per point).

As decidualization proceeded, the volume of extracellular space showed a steady decline (Figs 1 $\& 2$ ). The decrease in volume is consistent with the increase in size of decidual cells and the reported decrease in intercellular area as assessed histologically (Jollie \& Bencosme, 1965; O'Shea et al., 1983). The large extracellular space of uterine tissues is an important factor to be borne in mind in analyses involving total tissue content: for example, although Selcer \& Leavitt (1988) reported an accumulation of corticosteroid-binding globulin in hamster uterine tissues in comparison with other tissues, such a distribution would probably be consistent with the expected values for interstitial space. Although uterine blood volume (per unit weight of tissue) increased slightly during decidualization, it still represented only about $25 \%$ of the total extracellular space. Consequently, techniques involving rapid vascular washout before whole tissue analysis would do little to remove the majority of extracellular components.

The withdrawal of progesterone support results in the rapid regression of the decidual tissue, with a dramatic fall in tissue blood space and vascular permeability to albumin occurring within $12 \mathrm{~h}$ (Fig. 2b). This coincides with a marked and rapid fall in uterine blood flow (Edwards \& Milligan, 1987). This pattern of tissue space changes in decidual tissue was also seen following the cessation of daily progesterone injections (Edwards, 1987). In rats, Deanesly (1973) observed haemorrhagic degeneration of decidual tissue within $24 \mathrm{~h}$ of ovariectomy on Day 8 of pregnancy. 
How these changes in the vasculature are mediated, and whether they are a cause or a consequence of decidual regression, is unknown. Changes in steroid levels can induce dramatic changes in uterine blood flow (Spaziani \& Suddick, 1967; Edwards \& Milligan, 1987) and uterine blood flow may have an important role in controlling uterine events leading to the maintenance of successful pregnancy (e.g. Garris, 1983). In the rat and guinea-pig, a reduction in uterine blood flow preceded resorption of the decidua (Garris, 1983; Garris et al., 1983). Whether the primary effect of progesterone withdrawal is to reduce uterine blood flow, with regression of the decidual tissue being just a consequence to this vascular change (Garris, 1983), remains to be elucidated.

The significance of the changes in uterine extracellular spaces associated with the development and regression of the decidual cell reaction are unclear. It is not known whether they are important for the successful initiation and completion of either the decidual cell response or for trophoblastic invasion and/or embryonic development. The control of such processes is likely to depend on a complex interaction between endocrine, paracrine and intracellular signals. Many of the endocrine signals can be measured systemically and intracellular signal mediators can be examined in a variety of in-vivo and in-vitro situations. A full understanding of the uterine events associated with implantation and establishment of pregnancy, however, will depend on a much clearer understanding of both the nature and the regulation of the large amounts of interstitial fluid bathing the cells and serving as the intermediary transport medium.

\section{References}

Deanesly, R. (1973) Termination of early pregnancy in rats after ovariectomy is due to immediate collapse of the progesterone dependent decidua. J. Reprod. Fert. 35, $183-186$.

Edwards, C. (1987) Studies of the decidual cell reaction in mice and rats. Ph.D. thesis, University of London.

Edwards, C. \& Milligan, S.R. (1987) Uterine blood flow during the development and regression of the decidual cell reaction in ovariectomized, steroidtreated mice. J. Reprod. Fert. 81, 525-532.

Finn, C.A. (1977) The implantation reaction. In Biology of the Uterus, pp. 245-308. Ed. R. M. Wynn. Plenum Press, New York.

Finn, C.A. (1986) Implantation, menstruation and inflammation. Biol. Rev. 61, 313-328.

Finn, C.A. \& Martin, L. (1972) Endocrine control of the timing of endometrial sensitivity to a decidual stimulus. Biol. Reprod. 7, 82-86.

Finn, C.A. \& McLaren, A. (1967) A study of the early stages of implantation in mice. J. Reprod. Fert. 13, $259-267$

Finn, C.A. \& Pope, M. (1984) Vascular and cellular changes in the decidualized endometrium of the ovariectomized mouse following cessation of hormone treatment: a possible model for menstruation. J. Endocr. 100, 295-300.

Finn, C.A. \& Pope, M. (1986) Control of leucocyte infiltration into the decidualized mouse uterus. J. Endocr. $110,93-96$.

Foreman, H., Vier, M. \& Magee, M. (1953) The metabolism of ${ }^{14} \mathrm{C}$-labelled ethylene-diamenetetraacetic acid in the rat. J. biol. Chem. 203, 1045-1053.

Garris, D.R. (1983) Decidual tissue growth and regression in the guinea pig: regulation by uterine blood flow and relation to circulating progesterone concentrations. Endocrinology 113, 1599-1604.

Garris, D.R., Fair, J.B., Whitehead, D.S. \& Muse, P.D. (1983) Relationship between deciduoma formation and uterine blood flow in the pseudopregnant rat. Gynecol. Obstet. Invest. 15, 84-92.

Jollie, W.P. \& Bencosme, S.A. (1965) Electron microscopic observations on primary decidua formation in the rat. Am. J. Anat. 116, 217-236.

Law, R.O. (1982) Techniques and applications of extracellular space determination in mammalian tissues. Experientia 38, 411-421.

Li, J.C.R. (1957) Introduction to Statistical Inference. Edward Brothers, Ann Arbor.

McRae, A.C. \& Heap, R.B. (1988) Uterine vascular permeability, blood flow and extracellular space during implantation in rats. J. Reprod. Fert. 82, 617-625.

Milligan, S.R. (1987) The sensitivity of the uterus of the mouse and rat to intraluminal instillation. J. Reprod. Fert. 79, 251-259.

Milligan, S.R. \& Mirembe, F.M. (1984) Time course of the changes in uterine vascular permeability associated with the development of the decidual cell reaction in ovariectomized steroid-treated rats. J. Reprod. Fert. 70, 1-6.

Milligan, S.R. \& Mirembe, F.M. (1985) Intraluminally injected oil induces changes in vascular permeability in the 'sensitized' and 'non-sensitized' uterus of the mouse. J. Reprod. Fert. 74, 95-104.

O'Shea, J.D., Kleinfeld, R.G. \& Morrow, H.A. (1983) Ultrastructure of decidualization in the pseudopregnant rat. Am. J. Anat. 166, 271-298.

Psychoyos, A. (1960) La reaction deciduale est precedee de modifications precoces de la permeabilite de l'uterus. C. r. Séanc. Soc. Biol. 154, 1384-1387.

Selcer, K.W. \& Leavitt, W.W. (1988) Hamster uterine tissues accumulate corticosteroid-binding globulin during decidualization. Biol. Reprod. 39, 592-602.

Spaziani, E. (1975) Accessory reproductive organs in mammals: control of cell and tissue transport by sex hormones. Pharm. Rev. 27, 207-286. 
Spaziani, E. \& Gutman, A. (1965) Distribution volumes of sugars in the rat uterus, ileum and skeletal muscle as affected by estradiol. Endocrinology 76, 470-478.

Spaziani, E. \& Suddick, R.P. (1967) Hexose transport and blood flow rate in the uterus; effects of estradiol, puromycin and actinomycin -D. Endocrinology 81, $205-212$,

Received 17 November 1989 